\title{
Saintsavaism(s) and Nationalism: An overview of the development of the Serbian Orthodox phenomenon of saintsavaism, with a special focus on the contribution of Justin Popovic (1894-1979)
}

\section{Introduction}

In this article we will focus on the case of the Serbian Orthodox Church and the phenomenon called saintsavaism [светосавље], and in particular how the term was understood and developed by Justin Popovic, the foremost authority in the Serbian Church who wrote on the topic of saintsavaism and, moreover, provided the clearest and most systematic presentation of what, in his opinion, saintsavaism ought to be. Popovic (1894-1979) remains, to date, one of the most prolific and renowned theologians in the history of the Serbian Orthodox Church (SOC) whose impact goes far beyond the SOC, where he has been venerated as a saint since 2010. Within the SOC his influence and legacy are immense, largely due to his magnum opus, the three volumes of The Dogmatics of the Orthodox Church, which he worked on throughout his life. Internationally, he is best known for his works on ecumenism, for which he gained a significant following among traditionalist circles of the Orthodox Church, and, in particular, because of his book, The Orthodox Church and Ecumenism (1974). In this book (and throughout his other works) he provides a scathing critique of the contemporary ecumenical process, as well as of Western Christianity and "Western culture" in general. The crux of his critique is his belief that the "West" abandoned Christ (i.e., the God-man) in favor of Adam (i.e., a man). Saintsavaism, as a central theme of Popovic's writings, presents, at least in part, an alternative worldview, through which Popovic argues for a restoration of the primacy of Christ in all aspects of human civilization (i.e., the principle of the 'Primacy of the Divine' over the human), including the political.

With the fall of communism in Yugoslavia, the term, saintsavaism, left its ecclesial setting and underwent something of a revival in other social sectors, including the political sphere. This resulted in the term being associated with late $20^{\text {th }}$ century Serbian nationalism by several researchers. ${ }^{1}$ However, the increase in the popularity of the term saintsavaism was accompanied by very little understanding of what it, in fact, is, what it is supposed to be, or how it is connected with Justin Popovic and the SOC. Above all, what was lost was the (very rich) theological content of this phenomenon. This situation was aptly described by one Serbian author who wrote that, while "everyone knows what saintsavaism is, ... nobody is capable of explaining what it is." 2 The authors who wrote about the phenomenon may be more or less equally divided between supporters and critics. So, for example, saintsavaism is described by some as, among other things, the basis of Serbian national identity, ${ }^{3}$ a unique phenomenon in the history of Christianity, or a distinctive religious and social movement founded on the life and work of St. Sava. ${ }^{4}$ Still others have described it variously as a dangerous cocktail of the ecclesiastical and political spheres, a type of Orthodoxy ennobled by healthy Serbian nationalism, a hotbed of Serbian nationalism and expansionism, and ethnophyletism. As for the SOC itself, in the period of the 1990's there was no room for speculation as to the national character of Orthodox Christianity in Serbia, and the central role it played in the history of the Serbian nation. In an editor's note, contained in the official journal of the SOC, the Orthodoxy, [Правослаље], Prof. Dragan Terzic, in a text entitled, There is no Serbdom without Orthodoxy [Без Православља не Постоји Српство], wrote the following on the relationship between the Serbs as a nation, and Orthodoxy:

\footnotetext{
${ }^{1}$ Maria Falina, "Svetosavlje a Case Study in the Nationalization of Religion," Schweizerische Zeitschrift für Religions- und Kulturgeschichte 101 (2007), 505-527; Maria Falina, "Between 'Clerical Fascism' and Political Orthodoxy: Orthodox Christianity and Nationalism in Interwar Serbia," Totalitarian Movements and Political Religions 8 (2007), 247-258; Vjekoslav Perica, Balkan Idols: Religion and Nationalism in Yugoslav States (Oxford University Press, 2002); Vjekoslav Perica, "Religion in the Balkan Wars," Oxford Handbooks Online (October, 2014), https://bit.ly/3btG9U8 (accessed August 24, 2020); Jovan Byford, Denial and Repression of Anti-Semitism: Post-Communist Rehabilitation of the Serbian Bishop Nikolaj Velimirovic (Budapest; New York: Central European University Press, 2008); Milorad Tomanic, Srpska Crkva u Ratu i Ratovi u Njoj (Beograd: Medijska knjizara Krug, 2001).

${ }^{2}$ Mirko Dordevic, Negativna svetosavska paralipomena (Novi Sad: VPA, 2015), 12.

${ }^{3}$ Christos Mylonas, Serbian Orthodox Fundamentals: The Quest for an Eternal Identity (Central European University Press, 2003), 52-53.

${ }^{4}$ Jelena Grbic, "Svetosavlje - omen za numen pravoslavlja," Sabornost 7 (2013), 145.
} 


\begin{abstract}
"The Serbs were not erased from the world history of nations thanks to Christian Orthodox and Saintsavic ideals. Were the Serbs to deviate from, or abandon their Saintsavic orthodoxy, they would experience divisions and schisms, delusions and misfortunes, wanderings and holocausts." 5
\end{abstract}

For Terzic, one of the proofs of the intrinsic link between Serbdom (i.e., the national identity of the Serbs) and saintsavaism is the very existence of the Bosniak nation. Bosniaks, in his view, were merely Serbs who (1) never accepted Christian Orthodoxy (they were dismissed as Bogomils, i.e. members of a medieval Christian Gnostic sect), and who (2) were enticed by the material benefits offered by the Ottoman conquerors and eventually accepted Islam. In doing so, they abandoned their original national identity. ${ }^{6}$

In the first section of this article we will provide an analysis of the term saintsavaism during its formative period, and in the second section, the article will focus on, arguably, the pinnacle of this development - the works of Justin Popovic, in particular his seminal work on saintsavaism, namely "Saintsavaism as a Philosophy of Life" (1953). Herein, a brief overview of the main ideas of the book will be provided, since no translation of this important work of Popovic exists to date, though it is fundamental for a more thorough understanding of his other works, including his writings on ecumenism. Furthermore, we will attempt to establish whether the phenomenon of saintsavaism is indeed a form of ethnophyletism as some have suggested, and whether the charges of saintsavaism being a form of religious nationalism are warranted. ${ }^{7}$ This, in turn will help us understand whether the (ab)use of the term during the nationalist surge in late $20^{\text {th }}$ century Serbia was the result of a misappropriation of the term by nationalists or, whether it was inherent to the ideology of saintsavaism, as envisioned by its creators, and Justin Popovic in particular. In other words, how did the interplay between politics and religion unfold - was it a case of the nationalization of religion as some have suggested, or the result of the religiously inspired political transformation of Serbian society. Furthermore, given the religious component of the nationalist violence which it (saintsavaism) arguably inspired, this article will inquire whether saintsavaism is an exclusivist system in respect to the religious other.

\title{
1. The Serbian Orthodox Church and Saintsavaism
}

In what follows we will investigate the alleged nationalism within the Serbian Orthodox Church, particularly as this is related to the phenomenon of saintsavaism. A significant number of authors have identified "saintsavaism" as, practically speaking, the most adequate term to describe the nationalism found in the Church. ${ }^{8}$ The debate is often political or historical, but rarely (if ever) theological. For example, Tomanic's scathing critique ${ }^{9}$ of the activities of the Serbian Church during the Yugoslav wars of the 1990's is, at best, an overview of some troublesome and disturbing trends, statements and events found in and around the Serbian Church during those times, and, at worst, a biased and ill-intended interpretation of events, amounting to little more than a smear campaign. Others have opposed these types of interpretations. For example, Zdenko Sirka, a Slovak-Serbian theologian from the University of Prague, writes: "It [saintsavaism] is [neither] ... a 'fusion of Orthodox theology with national values,'

\footnotetext{
${ }^{5}$ Dragan Terzic, "Komentar Urednika," Pravoslavlje, 608 (15 Jul 1992), 3.

${ }^{6}$ The significance of this text, as an example of the nationalist discourse of the SOC (Pravoslavlje is the official journal of the SOC. This text was written by the editor of that journal in 1992 when tensions in Bosnia and Herzegovina escalated into open conflict - a war fought along religious lines. The SOC, to this day, describes itself often as a "saintsavic" (svetosavska) church, and celebrations of St Sava's feast day (January 27) are often used by the leadership of the SOC to underscore the importance of Orthodox Christianity in general, and the SOC in particular, for the formation and preservation of Serbian national and cultural identity. For a critical assessment of the involvement of the SOC during the Yugoslav Wars, in addition to the references in footnote 1, see: Mirko Djordjevic, "Ratni Krst Srpske Crkve [The Serbian Church's Cross of War],"Republika 273(2001), available online at: Mirko Djordjevic, "Ratni Krst Srpske Crkve [The Serbian Church's Cross of War]," Republika \& Yurope (n.d.), accessed October 15, 2020, https://bit.ly/3kgWKy2.

7 Jelena Subotic, "The Church, the Nation, and the State: The Serbian Orthodox Church After Communism," Orthodox Churches and Politics in Southeastern Europe: Nationalism, Conservativism, and Intolerance, ed. Sabrina P. Ramet (London: Palgrave Macmillan 2019), 100-102.

${ }^{8}$ Branimir Anzulovic, Heavenly Serbia: From Myth to Genocide (NYU Press, 1999); Sabrina P. Ramet and Vjeran I. Pavlakovic, Serbia Since 1989: Politics and Society under Milosevic and After (University of Washington Press, 2011).

${ }^{9}$ Tomanic, Srpska.
} 
... [nor] 'a common Serbian term for the peculiar blend of church, state, and nation'."10 Other related studies $^{11}$, for the most part, are historical studies which focus on the socio-historical context of the idea of "saintsavaism," with little to no attention given to its theological aspect. ${ }^{12}$ Indeed, there is scarcely any knowledge of, or familiarity with, this element of his work outside of Serbia. ${ }^{13} \mathrm{He}$ is known instead mainly for his anti-ecumenical and anti-Western writings, most notably in The Orthodox Church and Ecumenism (1974). These writings, too, are, however, essentially, incomprehensible without an understanding of "saintsavaism."

In effect one could speak of at least four distinct streams of interpretation of the phenomenon of saintsavaism: 1) proto-saintsavaism, from the development of the term to its adoption by $\mathrm{N}$. Velimirovic, 2) the saintsavaism of N. Velimirovic, 3) the saintsavaism of J. Popovic, which represents the systematization of previous iterations as well as serving as the foundational element of the entire theology of J. Popovic, second only to Popovic's Christological understanding of reality, observable in his widespread usage of the term "God-man" [богочовек]; and 4) post-communist saintsavaism.

Before we proceed, some introductory remarks need to be made regarding the person and the eponym of saintsavaism, namely, Saint Sava.

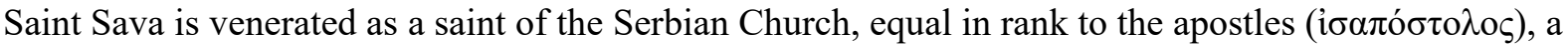
patron saint of Serbian education and of Serbia. Saint Sava was a Serbian prince-bishop and one of the most important figureheads of Serbian history in general. He was born in the late $12^{\text {th }}$ century (1169 or 1174), as Rastko Nemanjic, into the ruling Nemanjic family, as the youngest of three brothers. Rastko left his native Serbia around 1192 to go to Mount Athos where he was tonsured as a monk, in the monastery of St Panteleimon, taking the monastic name Sava (Sabbas). The decision to leave behind all worldly possessions and accept a monastic life of asceticism, that is, to choose the heavenly over the earthly (i.e., the primacy of the divine over the human), will appear as one of the key elements of saintsavaism. Upon his return to Serbia from Mount Athos, Saint Sava became instrumental in obtaining autocephaly for the Serbian Church from the Patriarchate of Constantinople in 1219. Moreover, he is credited ${ }^{14}$ with writing the de facto first constitution of the Serbian Kingdom. In effect, he helped to establish the temporal and ecclesial independence of the Serbian medieval state, and more importantly for the Serbian Church, he managed to steer the new kingdom to the Byzantine (Orthodox) sphere of influence.

\subsection{Proto-saintsavaism}

As we have shown, the importance of Saint Sava for both the Serbian Church and Serbian national identity cannot be overstated. That being said, the term we are discussing here, saintsavaism, appeared relatively late in relation to the long-standing cult of the Serbian saint. It was not until the early $20^{\text {th }}$ century that the term was first coined and saw further use. The interwar period in Serbia saw an increase in academic activity on the part of the Serbian religious intelligentsia. This development, and in particular the "spread of Western ideas", did not however resonate well within some circles of Serbian society, and the search was on for an alternative to the "modern materialistic" civilizational trends (i.e., Western ideas) which were spreading through Serbian society. In a sense, the emerging movement was, to a point, a reactionary one, describable as both antimodernist and anti-Western. The key event in the

\footnotetext{
${ }^{10}$ Zdenko Sirka, "Transformation in the Theology of Tradition: A Study of Justin Popovic and His Hermeneutical Presuppositions," Ostkirchliche Studien 67, (2018), 328.

${ }^{11}$ Ramet and Pavlakovic, Serbia; Byford, Denial; Falina, "Svetosavlje”; Falina, "Between"; Grbic, "Svetosavlje."

${ }^{12}$ For an overview of recent theological works regarding J. Popovic, which often overlap with the topic of saintsavaism look to Sirka, "Transformation."

${ }^{13}$ Notable exceptions include, Klaus Buchenau, "Svetosavlje und Pravoslavlje. Nationales un Universales in der serbischen Orthodoxie," Nationalisierung der Religion und Sakralisierung der Nation im östlichen Europa, ed. in Martin Schulze Wessel (Stuttgart: Franz Steiner, 2006), 203-232; and Thomas Bremer, Ekklesiale Struktur und Ekklesiologie in der Serbischen Orthodoxen Kirche im 19. und 20. Jahrhundert (Würzburg: Augustinus-Verlag, 1992). Buchenau's chapter went into some detail into the historical development of svetosavlje, however, his analysis was much more focused on Velimirovic and the early period of Saintsavaism, than on Popovic. This text expands upon Buchenau's study and offers a more nuanced interpretation of Popovic's contribution to the development of saintsavaism.

${ }^{14}$ Dimitrije Bogdanovic, "Sveti Sava (Predgovor)," Sveti Sava, Sabrani spisi, Stara srpska književnost u 24 knjige, ed. Dimitrije Bogdanovic (Beograd: Prosveta I Srpska Knjizevna Zadruga, 1986), 19.
} 
term's history, according to some, was the establishment of a scientific journal under the name Saintsavaism [Светосасвље], which ran from 1932-1940, by a group of young Serbian theologians. The person working alongside them and the one who gave a name to this movement was a prominent Serbian theologian, Dimitrije Najdanovic. ${ }^{15}$

It was during this period (1933) that one of the earlier (if not the earliest) attempts to define saintsavaism was undertaken. A young Russian émigré, Teodor Titov, tried to offer a program based on the saintsavic idea that developed around him. ${ }^{16}$ Titov describes saintsavaism as both "unique sui generis in the history of Christianity," and, moreover, "a spiritual religious and societal movement based on the person, life and legacy of St. Sava." The essence of saintsavaism is described as "a magnificent manifestation of the lifegiving spirit and power of Orthodox Christianity." The significance of saintsavaism, according to the author, is in the genuine witnessing of true Christianity, otherwise lost in the times they were living in. In addition to offering the preferred ascetic, and monastic ideal for his followers to emulate, the author highlighted the political dimension of saintsavaism. For the author, saintsavaism is an Orthodox variant of pan-Slavism, and especially 'yugoslavism' (i.e., south Slavism). That said, saintsavaism is unmistakably Serbian, since it (saintsavaism) was the only bulwark that allowed the preservation of the Serbian tribe during its centuries of slavery and, in the opinion of the author, remained a foundation for a Serbian Church, state and culture, as well as the centerpiece of the Yugoslav state. ${ }^{17}$ St. Sava is presented as someone who is not only worthy of reverence in view of his societal achievements, but also in his role as an exemplar of saintly life, to be emulated down to the tiniest details.

\subsection{The saintsavaism of Nikolaj Velimirovic}

The other great figure of these early days of saintsavaism was Nikolaj Velimirovic, at the time one of the more revered theologians and bishops of the Serbian Church, and since 2003 a saint of the Serbian Orthodox Church. Both Titov and Velimirovic were involved with the magazine Svetosavlje, and they constituted the two driving forces behind the successful spread and adoption of the term in academia and in popular piety. The former, as we mentioned, is related to the publishing activities of the Svetosavlje journal, and the latter with the lay popular pious movement called the bogomoljci (the God worshippers). There are reasons to believe that there was a significant overlap between the two, since Velimirovic was also involved with the publication of the journal. Moreover, he was (and is still) considered one of the most respected theologians of the Serbian Church. The relationship between the bogomoljci, as one of the rare examples of mass pietistic movements in the SOC, and its troubled relationship with the leadership of the SOC, and the nationalist interpretations of saintsavaism might provide an interesting field of research for future research.

Velimirovic's interpretation of saintsavaism became the focus of several studies ${ }^{18}$ which linked saintsavaism with national-socialism. These studies usually tend to focus on a speech delivered in Belgrade in 1935, namely the "Nationalism of Saint Sava," in which Velimirovic draws a connection between St Sava and Adolf Hitler. ${ }^{19}$ This claim, however, was subject to some criticism, and it has been argued that, at worst, one could speak of an error in judgement on the part of Velimirovic, with regards to the character of the German dictator. ${ }^{20}$ This discussion, however, is beyond the scope of this article. Similarities abound between the earlier text of Titov and the speech by Velimrovic (e.g., the centrality

\footnotetext{
${ }^{15}$ Dimitrije Najdanovic, Svetosavlje i Pravoslavlje (Beograd: Nova Crkva, 2009), 30.

${ }^{16} \mathrm{He}$ also authored another work on st. Sava several years later, Teodor Titov, Sv. Sava, kao pastir i tvorac istoriskog srpsko-pravoslavnog pastirstva (Nis: Stamparija Sv. Konstantin 1936).

${ }^{17}$ Teodor Titov, "Svetosavlje," Svetosavlje 3-5 (1933), 97-104.

${ }^{18}$ Falina, "Svetosavlje"; Sabrina P. Ramet, "The New Church-State Configuration in Eastern Europe," East European Politics and Societies 5 (1991), 247-267; Anzulovic, Heavenly.

${ }^{19}$ Falina, "Svetosavlje" 522; Anzulovic, Heavenly, 30.

${ }^{20}$ Vladimir Cvetkovic, "St. Nikolaj of Zhicha's Lecture 'Nationalism of St Sava' Reconsidered," Crkvene Studije 16 (2019), 131-148; Byford, Denial, 47-55. The arguments brought forth by prof Cvetkovic may clear up some of the confusion regarding that particular speech, however, there are numerous other instances where Velimirovic's nationalism was apparent. Velimirovic's works in the latter stage of his life, in particular during his exile in the US, clearly show that he did hold nationalist views, and in fact, saw nationalism as equivalent to patriotism (i.e., a virtue). See Nikolaj Velimirovic, "Cetiri Vrline Svetoga Save [The Four Virtues of St Sava]," Sabrana Dela Episkopa Nikolaja u XII Knjiga v. X (Sabac: Manastir Sv. Nikolaja; Soko, 2016), 694-697.
} 
of the SOC for the preservation of the Serbian people), though there are significant differences as well. Whereas Titov highlighted the ecumenical and pan-Slavic qualities of saintsavaism (i.e., supra-national qualities), ${ }^{21}$ Velimirovic held different (even opposing) views. In this speech, Velimirovic claims that no nation, or nation state, can successfully exist without a national church and, in a roundabout fashion, he criticizes the Roman Catholic Church for her a-national character. ${ }^{22}$ Moreover, for Velimirovic, nations, and by extension, the national designation of churches, have a biblical (divine) origin: "The Savior Himself ordered to the apostles: Go therefore and make disciples of all nations (Mt 28:19). By those words He recognized nations [народе] as natural units of His Universal Church."23 Pan-Slavism (i.e., supra-nationalism), as a political option, and yugoslavism in particular, were abandoned in Velimirovic' saintsavaism, and were replaced with (Serbian) nationalism. This is not to say that Serbian national identity was absent prior to Velimirovic. On the contrary, it was framed within the service of a wider south-Slavic movement. For Velimirovic, saintsavaism's political implications, which he claims are based on Scripture, essentially translate into the following: one nation requires one national church, and a national (i.e., of the same nationality) dynastic ruler, faithful to the one national church, who then governs the one national state, which should extend as far as there are members of the same nationality. ${ }^{24}$

All told, for Velimirovic the national identity and, in particular, Serbian national identity within saintsavaism, were re-envisioned (in relation to the earlier saintsavaists) as playing a more central role in a distinctly mono-national political entity. In effect, we could speak of a "nationalist turn" in saintsavaism starting with N. Velimirovic. It may well be that this "nationalist turn" was merely a result of the rise of nationalism throughout Europe at the time (mid-1930's). This is a distinct possibility, given the thesis proposed by the American scholar Michelle Margolis, who recently identified a trend in which religious views are in fact influenced by political views - in effect, an individual's exclusivist (i.e., nationalist) political outlook leads to a more exclusivist interpretation of religion. ${ }^{25}$

\section{The Saintsavaism of Justin Popovic}

Velimirovic's contributions to the development of the idea of saintsavaism are indeed, numerous, and his interpretations of the term were and remain relevant for a comprehensive understanding of saintsavaism. That being said, the discussion was rendered moot, so to speak, by his spiritual descendant and one-time pupil, Justin Popovic. According to Veimirovic, it was Justin Popovic who pronounced the final word on saintsavaism. What, then, is saintsavaism for Justin Popovic? According to Sirka, "whenever Father Justin mentions svetosavlje or Orthodoxy, we can read it simply as 'Christianity'." 26 Could it be that simple? Were this indeed the case, why might one not then speak simply of Christianity? Why is there a need for the alternative? Moreover, since orthodoxy is a synonym for Christianity, the case becomes even more complex. After all, in addition to orthodoxy, other variants of Christianity. Are they all, then, synonymous with saintsavaism? How does the expression, "saintsavaistic orthodoxy" (svetosavsko pravoslavlje), ${ }^{27}$ relate to Orthodox Christianity? Clearly, there is more at stake here than a linguistic preference.

\subsection{The System of Saintsavaism}

In the 'Foreword' to Popovic's book on saintsavaism (Saintsavaism as a Philosophy of Life, 1953), Velimirovic writes that Popovic's take on saintsavaism represents "the first exposition of saintsavaism

\footnotetext{
${ }^{21}$ Titov "Svetosavlje," 102-103.

${ }^{22}$ Nikolaj Velimirovic, "Nacionalizam Svetog Save [The Nationalism of Saint Sava]," in Nikolaj Velimirovic, Sabrana Dela Episkopa Nikolaja u XII Knjiga v. IX (Sabac: Manastir Svetog Nikolaja, Soko, 2016), 307, 311.

${ }^{23}$ Velimirovic, "Nacionalizam," 307.

${ }^{24}$ Ibid., 307-8.

${ }^{25}$ Michelle Margolis, From Politics to the Pews: How Partisanship and the Political Environment Shape Religious Identity (Chicago: University of Chicago Press 2018).

${ }^{26}$ Sirka, "Transformation" 330. According to the author, saintsavaism is also a logos-centric philosophy of the world and a description of the world and Orthodox identity historically, and permanently connected with the person of St Sava (i.e., it is apparently not simply a synonym).

${ }^{27}$ Popovic, Svetosavlje, 226. "Do you know what it means to be saintsavaisticly orthodox? It means to continuously fight with passions and sins within yourself and the world."
} 
as a unique and a holistic system, and moreover, as a philosophy of life." ${ }^{28}$ According to Popovic, within the saintsavaistic system there exists a saintsavaistic philosophy: of creation, of progress, of culture, of society, of values and merits (i.e., saintsavaistic ethics), and of education. Methodologically speaking, Popovic presents each of these "philosophies" in roughly three movements. In the first, he offers a critical assessment of the lamentable state of the matter (in the "West" or in "Europe"). In the second, he proceeds to offer arguments defending the view that (Orthodox) Christianity is a superior alternative to existing philosophical and religious systems. Finally, in the third movement, St Sava is presented, by Popovic, as the individual who managed to realize this Christian alternative worldview (i.e., the different philosophies), as a historical reality within the context of the Serbian medieval state. ${ }^{29}$

\subsubsection{The World in Saintsavaism}

Popovic's views on Creation (i.e., the World) are perhaps one of the more interesting aspects of his saintsavaism. In spite of his reputation as a harsh critic of all things non-Orthodox, here he offers a very positive outlook on the world in general. For example, on matter found in the world, Popovic writes: "All matter is a guardian of one of the thoughts of God, it follows then that every type of matter is a small gospel, since it preaches God and the thought of God as a tireless herald of God." Furthermore, Popovic writes, "Matter is something divine, something of the Logos, because it [matter] too was created through the Logos." ${ }^{30}$ From this, Popovic derives two basic principles of his saintsavic philosophy of the world. The world is a revelation [богојављење], and since the only suitable response to God's revelation is worship, it follows that that humanity is a liturgy [богослужење] (i.e., the worship of God).

\subsubsection{Saintsavic Progress}

For Popovic, a saintsavic philosophy of progress is inseparable from the question of death. Popovic claims that, if death remains undefeated, all perceived progress is an illusion, and in fact, only brings about more death. The problem of death, for Popovic, exposes the shortcomings of science, philosophy, and other religions in one fell swoop, since none of these human attempts at solutions have, in fact, found a way to defeat death. Without this victory over death, "what is all of human progress, but progress towards death, progress towards the grave?" ${ }^{11}$ The event of Christ's resurrection divides the whole of human history in two parts: prior to the resurrection, when death was unavoidable; and after the resurrection when immortality became unavoidable. For Popovic then, only progress based on the resurrection of Christ, is true progress, what he calls "theanthropic progress [богоочовечански прогрес]." Furthermore, the (Orthodox) Church is nothing less than an uninterrupted and endless extension of that historical event of the resurrection. ${ }^{32}$ In this manner, Popovic ties the possibility of genuine, and worthwhile, progress to the Orthodox Church, a decision undoubtedly influenced by the atheist and secularist narratives of the time, which claimed that progress is solely reliant on ultimately discarding religion, in favor of positivistic science. In addition to having the potential to genuinely affect society at large, theanthropic progress is also individual (i.e., personal).

"Only through faith in the resurrected God-man does a human becomes a human, by liberating oneself from sin and death, and by attaining the sense for immortality. Sin is a disease that dulls, handicaps, and paralyses the sense for immortality, and as a result a human cannot, either by his feelings or through his thoughts, reach God as true and living. Such a human is a crippled one, a half-human, a sub-human." ${ }^{33}$

There are no indications in this book, or the rest of his works, that Popovic did not apply the same line of exclusivist reasoning retroactively, i.e., that true humanity was unachievable before the event of the resurrection, and the establishment of the Church. The exclusivism on display here, however, is related

\footnotetext{
${ }^{28}$ Popovic, Svetosavlje, 176.

${ }^{29}$ Ibid., 237-238.

${ }^{30}$ Ibid., 187, 189.

${ }^{31}$ Ibid., 194-198. Quote on p.198.

${ }^{32}$ Ibid., 201.

${ }^{33}$ Ibid., 209.
} 
to the ecclesiology of Popovic, which does not foresee an opportunity for salvific potential outside the Church, including the opportunity for genuine progress. This theanthropic philosophy of progress is at the same time the "saintsavic philosophy of progress." In the concluding segment of this section on theanthropic progress, Popovic writes: "I have briefly presented the saintsavic philosophy of progress. For it was St Sava who was the most gifted and greatest architect [неимар] of theantropic progress in the history of our people. For the purposes of our national sensibilities, the ideology of true and authentic progress was given in the life and work of St Sava." 34

Saintsavism, when applied to Popovic's philosophy of progress, is more akin to the earlier protosaintsavaists than it is to his direct predecessor, N. Velimirovic. While Popovic (like Velimirovic), was still very critical of the non-Orthodox world, Popovic's saintsavaism does not include the ethnomessianic elevation of the Serbian people characteristic of Velimirovic. ${ }^{35}$ Popovic's saintsavic progress represents a local (i.e., ethnic) contextualization of what he understands to be theanthropic progress characteristic of the Orthodox Church in general.

\title{
2.1.3. Saintsavic Culture
}

Some elements of Velimirovic's claims regarding the particularity of the Serbian people are noticeable when Popovic describes the saintsavic philosophy of culture. Popovic understands and interprets culture as equal to, and synonymous with, civilization, in a Huntingtonian manner. ${ }^{36}$ Popovic repeats Velimirovic's claims about a technocratic, advanced, but ultimately hollow "West," as one type of a culture (i.e., civilization), and an underdeveloped, yet mystical and spiritual East as another culture. Ultimately, he asserts that Serbia should take a higher road, a road that is beyond the East and the West. One of the most remarkable theological claims Popovic makes, is that there exists a national soul, or the soul of a people, for which all members of that nation are responsible. There is, then, a collective responsibility, one shared by each and every individual Serb, for the soul of the whole Serbian people:

\begin{abstract}
"In the body of our people, our souls are intertwined as roots in the ground, out of which a single tree grows. All of us carry a piece of each other's souls, and all of our souls combined make for one indivisible organism. If my soul is poisoned with egoism, won't that poison spread throughout the whole people, and poison its soul as well? The health of the soul of our people is the responsibility of all of us, from the tiniest to the greatest, from the most learned to the illiterate..." 37
\end{abstract}

When Popovic used the term, "народ," which can be translated as "nation" and "people," he was not writing about the Serbian nation-state in any form, with perhaps the exception of medieval Serbia. If anything, the position of the nation-state in nationalist societies was something he opposed, and he criticized it as a form of idolatry. ${ }^{38}$

The discussion of the soul of a people is relevant for saintsavaism because of Popovic's introduction of saintsavic culture (i.e., civilization) as an alternative to the soul-less (i.e., dead) Western culture, which came to be that way because of the loss of its relationship with the (Orthodox) Church, and thereby with Christ. ${ }^{39}$ The proposed Saintsavic culture is built upon the person of the God-man Christ, and within this civilization Christ always comes first. Within this theanthropic civilization, the primacy of the divine extends to the creative processes as well. Popovic argues that, in every achievement of a civilization and an individual, within a saintsavic culture, it should always be affirmed that it was God

\footnotetext{
${ }^{34}$ Popovic, Svetosavlje, 210.

${ }^{35}$ Nikolaj Velimirovic, "Srpski narod kao Teodul [The Serbian People as a Theodulos]," Sabrana Dela Episkopa Nikolaja u XII Knjiga v. V, Nikolaj Velimirovic (Sabac: Manastir Svetog Nikolaja, Soko, 2016), 653-684. Also, Nikolaj Velimirovic, "Iznad Istoka i Zapada [Beyond the East and the West]" Sabrana Dela Episkopa Nikolaja u XII Knjiga v. V, in Nikolaj Velimirovic (Sabac: Manastir Svetog Nikolaja, Soko, 2016), 793-810.

${ }^{36}$ Popovic understands culture, much in the same way S. Huntington understands civilizations in his famous The Clash of Civilizations (1996).

${ }^{37}$ Popovic, Svetosavlje, 212-213.

${ }^{38}$ Ibid., 215.

${ }^{39}$ Ibid., 218. "What remains of a human when his soul is removed from his body - a corpse. What then of Europe when the soul is removed from her body? A corpse."
} 
who was working [Бог ради], and that humanity was collaborating [човек сарађуje]. The goal of a saintsavic culture is to introduce as much of the divine into humanity and creation as it possibly can. "In other words, [the goal of a saintsavic culture is] to incarnate God into humanity and creation." Moreover, the goal of saintsavic culture (to be achieved by the practice of biblical virtues), is "to transform not only the human, and humanity, but also, through them, nature itself." 40 The first commandment of saintsavic culture is outlined by Popovic in the following manner, "But seek first his kingdom and his righteousness, and all these things will be given to you as well (Mt 6:33)." The motto of saintsavic culture is that "a man [sic] is only great through God."

Saintsavaism, within this context (i.e., a theanthropic culture) is, for Popovic, simply a recognition of what he believed were the historical events which led to the Serbian people accepting Orthodox Christianity; hence the name, saintsavic culture. It is important to note that, within saintsavaism, the person and the character of St Sava are understood as almost equal to Moses. In much the same way as Moses took the Jewish people out of slavery and gave them the commandments of God to follow, St Sava, according to Popovic, undertook the same feat for the Serbian people: "He [St Sava] made a path for our soul from mortality to immortality, from temporality into eternity, and led it [the soul the Serbian people] on the path of theanthropic, orthodox culture." ${ }^{42}$ With this, Popovic clears away any doubt about whether this transformative and sanctifying culture could be anything but the culture derived from the Orthodox Church. St Sava, as was mentioned earlier, managed to influence his brother towards the Orthodox Church, and away from the Roman Catholic Church, and this "medieval lobbying feat" is recognized as one of his (St Sava's) greatest achievements.

All told, saintsavic culture, as envisioned by Popovic, might be described as a collectivistic type of a culture, within which each individual is responsible for the wellbeing of the entire people, and everyone is expected to accept the primacy of the divine in all aspects of their lives. The role of the Church within this culture is, therefore, equally overarching, since the Church, for Popovic, is Christ. Moreover, the goal of saintsavic culture - the sanctification of all of creation - is to be achieved through the practice of biblical virtues which, in turn, are only to be found in the Church. The Church, here and elsewhere in his works, is, for Popovic, the Eastern Orthodox Church, a fact which is confirmed by the references to St Sava's involvement in the decision of the Serbian medieval state to accept Eastern Orthodoxy as the official state religion as the "path to the theanthropic, orthodox culture." The concern that arises here is for those individuals who do not "go with the program" and accept the primacy of the Church, because they belong to other faiths, or are atheists. In other words, saintsavic culture (i.e., civilization), as envisioned by Popovic, is necessarily mono-religious, and this necessity derives from the relationship between the wellbeing of the "national soul" and the wellbeing of the entire people.

\subsubsection{Saintsavic Society}

Popovic's view on society is based on the same principles as those outlined above. Furthermore, Popovic's "perfect society" is explicitly identified as the (Orthodox) "Church," as a logical consequence of that society growing out of Christ, and moreover being Christ. ${ }^{43}$ The basic principles of a saintsavic philosophy of society, according to Popovic, are as follows: "The Church is a theanthropic organism first, and a theanthropic organization second. From this, it follows that her [the Church's] activities in the world should focus on incarnating everything that is theanthropic into individuals, and the society alike." ${ }^{44}$ Furthermore, Popovic sets out a basic rule for his saintsavic society."[T] $]$ he rule above all rules is as follows: do not conform the God-man Christ to the spirit of the time, conform the spirit of the time to the spirit of Christ's eternity..." ${ }^{45}$ In other words, the Church has no need, nor should it ever consider a need, for an aggiornamento. If a divergence occurs between the Church and society on certain issues, it is society that should conform to the position of the Church. Elsewhere, he highlights this uncompromising attitude explicitly. "According to the saintsavic philosophy of life and the world, all

\footnotetext{
${ }^{40}$ Popovic, Svetosavlje, 219-220.

${ }^{41}$ Ibid., 221-223.

42 Ibid., 226.

${ }^{43}$ Ibid., 231

${ }^{44}$ Ibid., 233

45 Ibid., 237.
} 
individuals, the society, the people, and the state are to conform to the Church as an eternal ideal. The Church should by no means conform to them, and even less so to be their slave." 46 The value of a people, and by extension the state, is measured, by Popovic, according to the prevalence of biblical virtues among that people. ${ }^{47}$ The upshot of this is that (within saintsavaism at least) any people, or state, which does not accept the Orthodox Church (i.e., the only source of virtues) has no value - nor does its people. Popovic's point may have been related to the salvific potential of those societies which, in his view, are lacking Christ. However, that being said, such a line of reasoning, expressed in such strong language, has had a significant potential for abuse.

\subsubsection{Saintsavic Values}

A Saintsavic philosophy of values is, in Popovic's own words, "an uprising and a turnaround against the basic principle of Western philosophy, namely, that the human is the measure of all things." 48 Popovic also ties his saintsavic philosophy to one of the more important historic events in Serbian history, the 1389 Kosovo Battle ${ }^{49}$ The choice of a part of the Serbian nobility to die fighting against the overwhelming force of the Ottoman Turks, thereby preserving their faith and liberty, is presented by Popovic as the epitome of the saintsavic philosophy of values (i.e., the Kosovo Gospel), given to the Serbian people by St Sava, which in turn, allows for it to be called the Saintsavic Gospel. Popovic here also gives his view on what it means to be a Serb, according to this saintsavic Gospel: "It means to hold the God-man Christ as the highest value and cherish Him above everything, further still to always make the choice for the Kingdom of Heaven over an earthly kingdom." ${ }^{.50}$ In relation to other aspects of saintsavaism, a saintsavic philosophy of virtues, Popovic's presentation has a significantly increased national character, which is evident, in particular, in the reference to the Kosovo Cycle. ${ }^{51}$ The choice to define what constitutes a proper Serb is problematic, since it negates the possibility of communal belonging to anyone who is not Orthodox (e.g., atheists, Muslims, Jews, Roman Catholics).

\subsubsection{Saintsavic Education}

Lastly, Popovic's philosophy of education is determined by what he regarded as the goal of all education, namely, the perfection of humanity. In his search for a teacher who can impart this knowledge, Popovic lists a number of notable individuals (Plato, Buddha, Moses, Muhammed, Kant,

\footnotetext{
46 Popovic, Svetosavlje, 237-238.

${ }^{47}$ Ibid., 238.

${ }^{48}$ Ibid., 251.

${ }^{49}$ A medieval battle between the Ottoman forces of Sultan Murad I, and the allied forces of prince Lazarevic which took place on June 28, 1389. The end result was the deaths of both army leaders and of a large number of Serbian nobility, the disappearance of the Serbian medieval state some 70 years later, and, ultimately, the subjugation of the Serbian people to Ottoman rule for several hundred years. Within the Kosovo narrative, prince Stefan Lazarevic (c.1377-1427) became a key figure in Serbian national legendarium, and next to St Sava the greatest figure in Saintsavaism - with St Sava occupying a position of a lawgiver and a Pater Patriae (akin to that of Moses in the history of the Jewish people). Prince Stefan, i.e. Prince Lazar, as he came to be called, took up almost a Christ-like position, due to his actions at Kosovo confirming St Sava's covenant between the Serbian people and God (i.e. the Kosovo Covenant). This conscious choice for martyrdom was perceived as the penultimate expression of the saintsavic principle of the Divine over the human, and with regards to Popovic's work discussed here, merely an example of a life lived according to saintsavic philosophy.

${ }^{50}$ Ibid., 252-253.

${ }^{51}$ Kosovo has been at the heart of nationalist discourse in Serbia for several decades. Although always a centerpiece of nationalist narratives, Kosovo gained in relevance as the issue of Serbian nationalism, after the NATO intervention of 1999, which resulted in the establishment of Kosovo as an independent state in 2008. Kosovo's independence was met with mixed international response, with Serbia being the most vocal opponent. The SOC, for its part maintained the centrality of Kosovo as the heartland of Serbia, and an area with incalculable cultural and spiritual value for the Serbian people and the Serbian Church, due to numerous medieval-Serbian-Kingdom-era monasteries and churches being there. Moreover, in order to further strengthen and emphasize the historical ties with the region, the SOC in 2018 proposed a revision of the Constitution of the SOC and suggested the change of the SOC's official name to "The Serbian Orthodox Church - The Patriarchate of Peja." Furthermore, the full title of the Serbian Patriarch is "His Beatitude the Archbishop of Peja, the Metropolitan of BelgradeKarlovci, and the Patriarch of Serbia." With regards to the relevance of Kosovo for Popovic, one would not be wrong to surmise that the land itself was of a lesser value to him than the protection of the Serbian people and the Serbian holy places dispersed throughout the region. This is, incidentally, the only context in which Popovic wrote favorably of a political and military mobilization of the priesthood. See: Justin Popovic, "Svetosavsko svestenstvo i politicke partije [The Saintsavic Priesthood and the Political Parties]," Setve i Zetve: Clanci i manji spisi, ed. Atanasije Jevtic (Beograd: Naslednici oca Justina, Manastir Celije, 2007), 551.
} 
Shakespeare, Goethe, Tolstoy, Nietzsche) and argues that all are inadequate to perform such an important task (i.e., perfecting humanity). The only one who is suitable to such a task is the God-man Christ, precisely because, in Him, the "divine perfections were ... humanly real and tangible." ${ }^{52}$ In other words, Christ is the perfect teacher, as well as the goal, the essence, and the ideal of education. Saintsavic education is, therefore, based on the God-man, as is everything else that is saintsavic. Popovic proposes what he describes as the general directives of saintsavic education. Through these "directives," he offers an alternative to the godless "European" (i.e., Western) education developed on the basis of the ideals of the Renaissance and the Enlightenment. The latter, in his view, had issued a dehumanizing process which brought forth subhuman automatons. ${ }^{53}$ Popovic's directives were as follows:

"1) A human is a being that can be perfected in the most ideal, and the most realistic way through the God-man. 2) The perfecting of humanity, with the God-man, is achieved through the biblical virtues. 3) An educated (enlightened) [i.e., saintsavic] human sees in every other human his immortal brother. 4) Every human activity: philosophy, science, crafts, agriculture, art, education, culture receives its lasting value when it is sanctified by the God-man and thought through in a theanthropic manner. 5) True enlightenment is achieved by means of a sanctified life, one lived according to the Gospel of Christ. 6) Saints are the most perfect educators. The saintlier a person lives, the better an educator they will be. 7) The school is the first half of the heart of the God-man, and the Church is the second. 8) At the center of all centers, ideas, and activities is the God-man Christ and his theanthropic collective, the Church." 54

In his concluding remarks, Popovic made a rare attempt at defining exactly what he understood saintsavaism to be. "Saintsavaism is an entelechy, the supreme principle, the lifegiving principle and force of our soul, our history, our people, our man [sic]; it is the soul of our soul, the heart of our heart, the life of our life." To abandon saintsavaism is to abandon everything that makes the Serbian people who they are, and the source of their greatness. This flows from the fact that everything that was great in the history of the Serbian people was inspired by St Sava.

\subsection{Nationalism, ethnophyletism and Saintsavaism}

Popovic's variant of Saintsavaism has a remarkably positive outlook on the world, with a strong sense of responsibility, appreciation, and wonder for all of Creation. In effect, we could even make the claim that, regardless of anything else, it is, in fact, an environmentally friendly ideology. ${ }^{55}$ However, Popovic emphasizes the invisible (i.e., spiritual aspect) over the visible, introducing a recurring theme, namely, the primacy of the invisible (i.e., the spiritual, the divine). Humanity, in general, is highly regarded, within the saintsavaism of Popovic. So, for example, he remarked that, "A human is the most wonderous and most superb workshop, in which there is continuous and mysterious streaming of the invisible into the visible, of the natural into the supernatural and vice versa." ${ }^{\text {} 56}$ However, Popovic's characteristic criticism of the West, in general, and what he identified as "humanistic culture," in particular, is also on display here. In fact, the whole project of saintsavaism could be interpreted as a reaction to humanism. This is particularly noticeable in the section on education, in which he explicitly states that saintsavaism is an alternative to the "godless humanism of the West." The point of separation between these two worldviews ("Western" humanism and saintsavaism) is the stance towards the primacy of the divinity in all aspects of human life (i.e., the role of the Church in society). ${ }^{57}$ In the opinion of Popovic,

\footnotetext{
52 Popovic, Svetosavlje, 254-256.

${ }^{53}$ Ibid., 261-264.

${ }^{54}$ Ibid., 265.

${ }^{55}$ A similar fascination with the natural world can be found throughout his works. For example, Justin Popovic, "Za dusom Cveca [For the Soul of the Flowers]" Setve i zetve, ed. Atanasije Jevtic (Beograd: Naslednici Oca Justina, Manastir Celije kod Valjeva, 2007): 809-813, and Justin Popovic, "Plava Ptica [The Blue Bird]" Zapisi, dnevnici, manja dela, ed. Atanasije Jevtic.(Beograd: Naslednici Oca Justina, Manastir Celije kod Valjeva, 2017), 693-696. Also look to Suncica Denic, "Govor cveca kao lirsko svedocenje istine oca Justina Popovica [The talk of flowers as Justin Popovic's lyrical witnessing of the Truth]" in Suncica Denic (ed.,) Otac Justin Popovic život i delo: Zbornik sa naucnog skupa (Vranje: Plutos 2015), 96-106. ${ }^{56}$ Popovic, Svetosavlje, 240.

${ }^{57}$ Popovic dismisses Yugoslav communism on this particular issue as well, namely the attempt to supplant the primacy of the Divine in the form of state-sponsored atheism. See: Neven Vukic, "The Church in a Communist State: Justin Popovic (18941979) and the Struggle for Orthodoxy in Serbia/Yugoslavia," Journal of Church and State (2020).
} 
Western secular culture is an attempt at a total removal of God from the life of humanity, whereas saintsavaism is an attempt to 'totalize' the role of the Church and, by extension, the "sanctification" of the whole of creation. Is this type of ideology, namely the saintsavaism of Justin Popovic, a nationalist one, or a form of ethnophyletism, as some critics have suggested?

While Popovic does not attempt to minimalize the national character of saintsavaism, the supposed "superiority" of saintsavaism vis-à-vis any other worldview does not derive from that national character. Instead, saintsavaism, as a proposed national ideology, is superior because it is a nationalized variant of the universal Orthodox Christian worldview. In other words, saintsavaism is superior to the West, because it is Orthodox. Therefore, the saintsavaism of Justin Popovic - at least in theory - cannot be regarded as nationalist. In other writings, Popovic reinforces the view that he was not supportive of nationalism of any kind:

\begin{abstract}
"Every human, as a creature of God, in their essence, is equal before God. The same applies for all peoples (народи). To claim that there is no 'chosen people,' is an idea coming from the Gospels. No nationalist chauvinism, or racism can be justified with the Gospel of Christ. The Orthodox faith does not allow for personal, national or racial 'sacred egoism'., 58
\end{abstract}

In other words, any nationalism that seeks to underscore the superiority of any given nation, based on human values and concepts, is not acceptable to, nor condoned by, Popovic. This rejection of nationalism is all the more intriguing, given that the relevant text was written in 1944 for a congress of representatives of the Chetniks - a Serbian nationalist movement. ${ }^{59}$ The strong language Popovic uses throughout his works, as well as the required foreknowledge of his oeuvre, meant that there was a possibility for both misunderstanding and misuse of this and other polemical texts he authored.

With regards to the charges of ethnophyletism, the situation is clearer, at least with regards to the way in which ethnophyletism is treated in the tradition of the Orthodox Church. Within the broader context of the Bulgarian national awakening, still under the rule of the Ottomans, the Bulgarian faithful clashed with the ecumenical patriarch over the presence of Greek-speaking clergy and their Hellenizing activities among the Bulgarian people. This included the use of Greek in the liturgy by the mid- $18^{\text {th }}$ century, instead of the Church-Slavonic. ${ }^{60}$ The Bulgarian authorities demanded ecclesial autonomy, which would allow for an independent election of hierarchs and the independent organization of religious life (i.e., an autonomous Orthodox Church). Subsequently, in 1872, the Bulgarian Church, with the permission of the Ottoman sultan, unilaterally pronounced its autocephaly. The parishes of the newly established Bulgarian Church, including the ones in Constantinople, were, reportedly, only open and accessible to Bulgarians. Soon thereafter, the Ecumenical Patriarchate responded by excommunicating all involved in that decision,. ${ }^{61}$ This is what is known as the Bulgarian Schism. ${ }^{62} \mathrm{~A}$ synod of the Church of Constantinople was promptly gathered that same year to condemn "ethnophyletism" as an ecclesial heresy of which the Bulgarian Church was declared guilty. The text of the condemnation reads:

"We condemn phyletism, that is, nationalist discrimination and ethnic strife and rivalry and divisions in the Church of Christ, as being contrary to the teaching of the Gospel and

\footnotetext{
${ }^{58}$ Justin Popovic, "O Crkvi," Setve i Zetve: Clanci i manji spisi, ed. Atanasije Jevtic (Beograd: Naslednici oca Justina, Manastir Celije, 2007), 217.

${ }^{59}$ Atanasije Jevtic, "Pogovor priredjivaca," Setve i Zetve: Clanci i manji spisi (Beograd: Naslednici oca Justina, Manastir Celije, 2007), 640. For this period, and more on the role of the chetniks look to, Mario Jareb, "Allies or Foes? Mihailovic's Chetniks during the Second World War," Serbia and the Serbs in World War Two, ed. Sabrina P. Ramet (London: Palgrave Macmillan 2011), 155-174.

${ }^{60}$ Basilius J. Groen, "Nationalism and Reconciliation: Orthodoxy in the Balkans," Religion, State and Society: The Keston Journal 26 (1998), 116.

${ }^{61}$ The excommunication of the Bulgarian Church lasted until after the Second World War, when in 1945 the schism was ultimately healed, and the Ecumenical Patriarch recognized the autocephaly of the Bulgarian Church.

${ }^{62}$ For more information on this topic look to: Dimitrios Thrassyvoulos Stamatopoulos, "Orthodox Ecumenicity and the Bulgarian Schism," Saint Vladimir's Theological Quarterly 57 (2013), 305-323; James Thornton, The Ecumenical Synods of the Orthodox Church: A Concise History (Etna, California: Center for Traditionalist, 2012), 148-57.
} 
the holy canons of our blessed fathers ... Those who accept such phyletism and who construct on this basis illicit assemblies (parasynagogai) that are new-fangled and nationalist, we proclaim, in accordance with foe holy canons, to be alien to the one, holy, catholic and apostolic Church, and thus to be schismatics." ${ }^{93}$

This anathema is often used as the prime example of the Orthodox Church's disassociation from, and condemnation of, nationalism and racism well before any other religious tradition. ${ }^{64}$.

The phyletism of the 1872 document is interpreted as being "the intrusion of chauvinism, even jingoism, in the administration or spiritual life of the Church within a given locale, when nationalistic pride trumps catholic humility and the Faithful, inappropriately, divide into ethnic ecclesiastical cliques." ${ }^{65}$ As can be seen, there are no elements of ethnophyletism in the positions of Popovic, his followers, or his predecessors. None of them exhibited any schismatic behavior with regard to the Orthodox oikumene on the basis of national, ethnic, or nationalist claims - which is what this anathema identifies as ethonphyletism.

\section{Concluding Remarks}

Saintsavaism, as a phenomenon within the SOC, does indeed involve a national component. However, whether or not is it a nationalist phenomenon, is a more complex question. We suggested that saintsavaism should be considered in at least 4 different stages. Out of those four stages, the second (i.e., the saintsavaism of N. Velimirovic), and the fourth stage (i.e., the post-communist saintsavaism) had some clearly national(-ist) overtones and, as such, should be more thoroughly analyzed. At no point in time, during the development of saintsavaism, could it have been labeled as ethnophyletism. From the analysis of Popovic's book on saintsavaism, two things of relevance can be deduced: 1) the saintsavaism of Popovic is not a nationalist ideology, though there is a powerful national component to it; 2) due to his polemical style of writing, and the interconnectedness of his works, there exists a significant potential for misunderstanding his oeuvre, and even its abuse, in particular by individuals with a nationalist background. In order to prevent similar abuses of his legacy, critical editions of his works are warranted. Within these critical editions, a properly contextualized setting of the texts should be provided, as well as clear indications of interpretations which are not in line with the wellestablished, anti-nationalist positions of Popovic. The current efforts, which focus on publications of the texts as they are found, with a minimalist editorial approach, are praiseworthy to the degree that they allow access to previously unavailable elements of his oeuvre, but the time has come for the next step, namely, a contextual and historical approach to his thought and practice.

\footnotetext{
${ }^{63}$ Kallistos Ware, “'Neither Jew nor Greek’: Catholicity and Ethnicity,” St Vladimir's Theological Quarterly 57 (2013), 239.

${ }^{64}$ Such as the Roman Catholic Church's condemnations via the 1939 encyclical Summi Pontificatus, and its unpublished predecessor, the 1939 encyclical Humani Generis Unitas.

${ }^{65}$ No authority in the Orthodox Church, except an ecumenical council, can issue a pan-Orthodox binding document, and even then, there are exceptions. Regarding this decision of the Patriarchate of Constantinople, it was authored by participants of a local Council, and as such, in its aftermath, the patriarch of the Patriarchate of Jerusalem refused to acknowledge this decision within his own patriarchate. Thornton, The Ecumenical Synods of the Orthodox Church, 156.
} 